Trinity College

Trinity College Digital Repository

Faculty Scholarship

Spring 3-2012

Contra Viento y Marea (Against Wind and Tide): Building Civic Identity among Children of Emigration in El Salvador

Andrea E. Dyrness

Trinity College, andrea.dyrness@trincoll.edu

Follow this and additional works at: https://digitalrepository.trincoll.edu/facpub

Part of the Education Commons, and the Social and Behavioral Sciences Commons 


\title{
Contra Viento y Marea (Against Wind and Tide): Building Civic Identity among Children of Emigration in El Salvador
}

\author{
ANDREA DYRNESS \\ Trinity College
}

This article examines contrasting approaches to citizenship education in two schools in San Salvador, El Salvador, in the face of highly visible transnational migration. I argue that while transnational realities challenge education for democratic citizenship, educational processes that enable students to interrogate their own transnational realities - in particular, their relationship to macrostructural relations of inequality-facilitate the development of critical, action-oriented civic identities. [civic identity, transnational migration, participatory research, democratic citizenship education]

Todos nosostros tenemos familia en los estados unidos. El que no tenga familia en los estados unidos no es salvadoreño.

[All of us have family in the United States. The one who doesn't have family in the United States is not Salvadoran.]

—high school student, El Rio

En la psique de la gente está siempre la opción de la migración ... te distrae de lo que tú podés hacer aquí.

[The option of migrating is always in people's psyche ... [It] distracts you from what you could do here.]

—high school teacher, Lincoln School

Globalization and the mass movement of people across borders has transformed the meaning of citizenship, and the implications for democracy and citizenship education in the United States has been the subject of lively debate (Abu El-Haj 2009a, 2009b; Flores and Benmayor 1998; Nussbaum 2002; Ong 1999; Rubin 2007). A rich body of social science literature has explored the impact of transnational ties on the incorporation of immigrants in host societies. Much less is known about the impact of transnational ties on the identities and affiliations of those in sending countries: the left behind children and relatives of migrants, returnees, and others affected by transnational migration. While a growing body of research on transnational families has pointed to the unique situation of children of migrants ${ }^{1}$ for the most part this research has not discussed the implications for citizenship and civic education in sending societies. Nor has there been a focused examination of how schools and educators in sending communities are (re)defining their roles in the context of transnational movement and dislocation. What should be the appropriate response of schools in communities where a significant percentage of their students will migrate to another country? Should they reorient their activities to foster "global citizenship" to best prepare their students for a life abroad? Or should they attempt to stem the tide of outward migration and encourage new commitment to the local? In short, how do educators in these communities conceive of their civic role in the face of massive cross-border movement and cultural flows?

This article examines contrasting approaches to citizenship education in two schools in San Salvador, El Salvador, in the context of highly visible transnational movement. El Salvador is one of the top sending countries of immigrants to the United States, and has experienced higher rates of emigration in the period since the end of their civil war, in

Anthropology E Education Quarterly, Vol. 43, Issue 1, pp. 41-60, ISSN 0161-7761, online ISSN 1548-1492. (C) 2012 by the American Anthropological Association. All rights reserved.

DOI:10.1111/j.1548-1492.2011.01156.x. 
1992, than ever before. In 2008-09, I spent 10 months in San Salvador conducting ethnographic fieldwork seeking to understand how transnational migration is affecting democratic citizenship education there. Given that El Salvador is a new democracy where education reform has been at the center of postwar reconstruction efforts, I was particularly interested to learn how participation in "transnational social fields" (Levitt and Glick Schiller 2004) encouraged students to think about democratic citizenship in El Salvador. In other words, did transnational networks push students to engage the particular social and economic realities of El Salvador that constrain democratic citizenship? Or did they deter such engagement? To what extent were educators conscious of these influences and intentional in their own efforts to foster civic identity?

As the opening quotes suggest, I found much evidence to suggest that transnational realities challenge education for democratic citizenship. Transnational fields of influence often directed students' focus away from local issues and problems that shape the exercise of citizenship in El Salvador. However, in this article I argue that students' experiences of transnational realities can provide a stimulus for the development of active civic identities, if educators are willing to engage them. My analysis of three different citizenship education programs, including a participatory research project I conducted with high-schoolaged youth on citizenship and migration in their community, suggests that educational processes that enable students to interrogate their own transnational realities-in particular, their relationship to macrostructural relations of inequality-facilitate the development of civic identities that are oriented toward democratic participation in El Salvador.

Whether educators consciously aimed for a "prolocal" conception of citizenship, as in one of my study schools, or a "proglobal" or "pro-North American" vision of citizenship, as in the other school, was ultimately less significant in shaping democratic citizenship education than how they engaged students in exploring their own realities. Although they followed widely different conceptions of citizenship, both schools adopted forms of civic education that avoided discussion of students' social location and their experiences with difference and inequality. Through a participatory research project in which my coresearcher and I engaged students in structured discussion and examination of their understandings of citizenship and the effects of migration, we learned that students were eager for the opportunity to talk about their experiences of migration and identity in school. They also expressed insightful critiques of their schooling and incipient dreams of what schooling could be. Based on this experience, I argue that participatory research is one way of engaging students in studying their transnational realities that becomes a form of civic education and produces critical, action-oriented civic identities. Participatory research yields unique insights into students' evolving self-understandings and civic identities even as it helps shape them.

\section{Transnational Social Fields, Civic Identity, and Democratic Citizenship Education}

Democratic citizenship education, as defined by Bradley Levinson, consists of "efforts to educate the members of a social group to imagine their social belonging and exercise their participation as democratic citizens" (2005:336). While the meaning of "democratic citizen" in any society has always been contested, it is made even more complex by global migration and transnational cultural flows. My analysis of citizenship education in El Salvador brings together evolving theoretical concepts from scholarship on transnational migration, youth civic identity in multicultural communities in the United States, and democratic citizenship education in the Americas. From the scholarship on transnational migration, the concepts of simultaneous affiliation and culture of migration direct our attention to the possibilities of transnational or postnational forms of citizenship, in which national identity is no longer the exclusive way of belonging. Scholarship on youth civic 
identity in the United States also sheds light on forms of civic identity that transcend national assimilation or facile patriotism, suggesting the need for educational processes that engage students in examining the paradoxes of citizenship within and across borders. And finally, scholarship on democratic citizenship education across the Americas illuminates competing conceptions of citizenship that inform school-based programs for citizenship education, highlighting patterns that pull away from practices of critical engagement with inequality. If transnational migration has dramatically transformed how young people "imagine their social belonging," the scholarship on civic identity and citizenship education examines the implications for how they "exercise their participation as democratic citizens."

Scholars Levitt and Glick Schiller (2004) propose the concept of "transnational social field" as a way of capturing the multiple affiliations and networks of migrants that are not contained within the boundaries of a single nation-state. They define social field as "a set of multiple interlocking networks of social relationships through which ideas, practices, and resources are unequally exchanged, organized, and transformed" (Levitt and Glick Schiller 2004:1009). A transnational social field approach to the study of migrant life opens up possibilities for "understanding the experience of living simultaneously within and beyond the boundaries of a nation-state" (Levitt and Glick Schiller 2004:1006). The concept of transnational social field challenges notions of citizenship that are bound to the nationstate, or any fixed categories of belonging as local, national, or global. "Movement and attachment is not linear or sequential but capable of rotating back and forth and changing direction over time" (Levitt and Glick Schiller 2004:1011). From this perspective, migrants emerge as capable of maintaining enduring ties with their homelands while still deepening their involvement in the host country: maintaining multiple, simultaneous affiliations. But if transnational ties do not preclude national assimilation for immigrants in host countries (see also Levitt et al. 2003), it remains to be seen how they affect national identification in sending countries, which are differently positioned within the global political economy. It may be that the pressure to assimilate experienced by migrants in the Global North becomes a pressure to migrate for their counterparts at home, tilting the scale away from national identity in the sending country. Kandel and Massey (2002) found, for example, evidence of a "culture of migration" in Mexican communities with high rates of out-migration to the United States, in which young people with family members who had migrated were more likely to aspire to migrate themselves, and less likely to stay in school in Mexico. They concluded that "the heavy involvement of Mexican communities and families in international migration contributes to a cultural milieu in which young people invest more faith in foreign wage labor than in Mexican education as a strategy for socioeconomic mobility" (p. 996). The existence of this "culture of migration" suggests a displacement of national identity for children of emigration, but the implications for civic identity is a topic for empirical investigation. The concept of simultaneous affiliations suggests that categories of affinity are not mutually exclusive; that identity is malleable, context-dependent, shifting over time in response to changing economic and political conditions. This insight turns our analysis to the ways young people experience and make sense of the multiple pressures they are subject to as they craft their own notions of citizenship.

Scholars of civic identity development among marginalized youth in the United States have suggested that the opportunity to explore disjunctures in citizenship, particularly the experience of inequality, can be a powerful stimulus for the development of critical, active civic identities (Abu El-Haj 2009a; Rubin 2007). Beth Rubin (2007) proposes a new conceptualization of civic identity development based on the civic experiences of youth, particularly those from marginalized communities, and the ways these experiences compare (or contrast) with the learned ideals of citizenship in the United States. Her 
research with diverse adolescents in four distinct school contexts highlights the importance of school opportunities to discuss students' own experiences with inequality for the development of active and engaged civic identities. Similarly, Thea Abu El-Haj (2009a), examining the citizenship experiences of Arab American youth in transnational communities, suggests that educators conceive of citizenship education as cultivating a set of critical practices that help young people "understand structural inequalities and work for social change within and across the boundaries of nation-states" (p. 275). Such an approach would more accurately reflect the changing nature of citizenship and belonging in the context of globalization, giving young people the skills to become active participants in civic, social, and political spheres that cross national boundaries, rather than equating citizenship with assimilation to national identity. She writes, "Participation and critical engagement, rather than a sense of national identification, may, in the end, prove a stronger base for developing engaged and active young citizens" (p. 281).

While Rubin and Abu El-Haj both highlight the need to engage students in exploring the contradictions of citizenship in their lives and communities, theirs and other research shows that this approach is not common. In a much-cited study of civic education in the United States, Westheimer and Kahne (2004) outline three conceptions of citizenship that inform educational programs for democratic citizenship: "personally responsible," "participatory," and "justice oriented." The justice-oriented approach, which engages students in discussion and analysis of social, political, and economic structures and emphasizes the need for social change, was the least commonly pursued. Of the three conceptions, personal responsibility received the most attention, or programs that "attempt to build character and personal responsibility by emphasizing honesty, integrity, self-discipline, and hard work" (p. 241). Westheimer and Kahne note that the emphasis on personal values and volunteerism distracts attention from analysis of the causes of social problems and the need for collective action, and could undermine democratic goals.

Within the Latin American context, the discourse of "values" is very prevalent among democratic citizenship education programs, and is often antithetical to a more justiceoriented vision of democratic citizenship (Levinson and Berumen 2007). In El Salvador, a discourse of values formation was adopted by the Ministry of Education in the mid-1990s, which, James Huff notes, "clearly placed the blame for young Salvadorans' social problems on their own shoulders" (2007:84). While the values associated with the personally responsible citizen are not necessarily in conflict with a justice-oriented conception of citizenship, in the context of El Salvador, where youth gangs became the target of increasingly brutal government policy and scapegoat for all of society's ills (Wolf 2009), the adoption of a values-formation discourse lends itself to the criminalization of youth and to social exclusion. As Huff writes, the values rhetoric has been invoked by MinEd officials to advocate "the view that Salvadoran youth are largely the victims of their own alleged pathological habits and philosophies" (2007:84). The tensions between the social justiceoriented and the values-based citizenship models in the context of extreme social inequality are of particular interest to this research.

\section{The El Salvador Context}

For young people growing up in El Salvador, the ties to the United States are many and varied. There are 2.5 million Salvadorans in the United States, comprising the fourth largest Latino group in that country, after Mexicans, Puerto Ricans, and Cubans. ${ }^{2}$ When added to the roughly six million people living in El Salvador, Salvadorans in the United States account for nearly one-third of the total Salvadoran population. Although El Salvador has a long history of migration to the United States, Salvadorans started arriving in large numbers in the 1980s, fleeing the civil war. The United States heavily funded the 
Salvadoran military's counterinsurgency against leftist guerillas in a war that left 75,000 dead and over 200,000 displaced. The Peace Accords were signed in 1992 and the FMLN, the former guerilla forces, became a political party. Rates of emigration did not decrease after the war, but have increased in the past 15 years as poverty and joblessness force more to leave than even the worst period of violence and human rights abuses. During the period of my research, some estimates placed the number of Salvadorans leaving the country daily at 700, while 150 deportees arrived back daily on State Department planes (and perhaps another hundred by land from Mexico). ${ }^{3}$

The remittances sent home by Salvadoran migrants largely sustain the economy, and account for the number one source of revenue for the country. Approximately 22 percent of households receive remittances, averaging $\$ 157$ a month. ${ }^{4}$ El Salvador is the only country in Central America to use the U.S. dollar as its sole form of currency, made possible by the influx of remittances. Along with the dollar, U.S. fast food chains proliferate, with U.S. prices. Since dollarization, the prices for basic goods and services have risen, while wages remain low. The minimum wage in El Salvador in 2009 was \$207.68 per month. In the maquila sector, it was $\$ 173.78$, and in agriculture, only $\$ 97.20$ per month. In 2006, the average household income was $\$ 247 /$ month, while the cost of la canasta del mercado (market basket) was $\$ 685$ (Dirección General de Estadística y Censos (DIGESTYC). ${ }^{5}$

In this context, emigration is a survival strategy, a response to the denial of basic citizenship rights at home. In 2007, the editors of a special issue of Estudios Centroamericanos devoted to migration asserted, "In no small measure, emigration has replaced the State in its obligation to ensure the welfare of the Salvadoran family" (2007, p. 4). Calling emigration the government's "most effective economic policy," they wrote, "El Salvador is able to maintain its current model of economic growth due to the fact that it massively expels a significant proportion of its population, which not only relieves social pressure internally, but also contributes in a determining manner through the sending of billions of dollars each year [in remittances]" (p. 8). ${ }^{6}$

During the historic election season of 2008-09, the year of my research, the role of the diaspora and emigration figured prominently in the campaigns. The leftist party, FMLN, which won the presidency in March 2009 for the first time in El Salvador's history, frequently invoked migration to critique the economic conditions under 20 years of ARENA rule. ${ }^{7}$ Both presidential candidates were interviewed by Univision's Jorge Ramos, addressing a transnational Salvadoran audience, and both were asked about why so many Salvadorans migrate to the United States. Mauricio Funes of the FMLN used the opportunity to expose weaknesses in ARENA's economic policy. ARENA's Rodrigo Ávila, for his part, maintained that the exodus had nothing to do with the standard of living in El Salvador, arguing that "the American Dream is always pursued by many people." The interview was such an embarrassment that ARENA tried to take it off the Internet.

It is clear that transnational ties are a determining force in El Salvador, and the country's political and economic future are inextricably tied to its relationship to the United States. But what does this mean for citizenship? My research suggests that Salvadoran educators are deeply concerned about the impact of migration on the identity formation of young people left behind. Yet, with little guidance from the State in addressing it, they are largely on their own to decide how to respond to the transnational realities of their students' lives.

My research partner and I selected two schools for our ethnographic fieldwork where transnational ties were highly visible in distinct ways: one representing the cosmopolitan elite and the other, transnational low-wage labor (Sassen 2006). Both aimed to play a leading civic role in Salvadoran society and were well known in their respective social spheres. The Lincoln School, ${ }^{8}$ an elite private school with an American curriculum, sprawls across a lush, landscaped 35-acre campus in one of San Salvador's poshest neighborhoods. 
One of several prestigious international schools in the city, the Lincoln School serves a 95 percent Salvadoran student body and only 5 percent international students, and has a local reputation as the emblem of, and gateway to, the Salvadoran elite. With several former presidents and vice-presidents among its alumni (prominently displayed in framed photographs on the lobby's "wall of fame"), the school prides itself on raising the future leaders of the country. A majority of the students have dual or triple citizenship and travel to the United States frequently (according to our survey of the senior class, roughly 60 percent had two or more passports). The school follows a U.S. curriculum and a U.S. high school structure with tracking and the corresponding features of hierarchy and choice: students may choose from 20 AP courses and over 100 total courses in the Upper School, and 32 different sports. Seventy-five percent of graduating seniors go on to college in other countries, the vast majority in the United States. At the school's graduation ceremony, the graduating seniors' names are called along with the name of the college they plan to attend and the state or country in which it's located. These features allow administrators to call the school "an American prep school in El Salvador."

On the opposite side of the city, amidst a hodgepodge clutter of brick and scrap metal homes along a polluted river, sits Centro Educativo Católico La Esperanza, a public school operated by a Jesuit NGO, ${ }^{9}$ serving students in one of the poorest and most violent neighborhoods of San Salvador. The residents of El Rio experience a much different side of migration to the United States, as family members of undocumented emigrants-loved ones left behind, waiting to go themselves - or as friends, neighbors, and family members of deportees. The young people we spoke to knew well the hardships endured by undocumented migrants, and they knew the costs for the families left behind. While the remittances sent home by family in the United States might keep food on the table, they don't keep young people from taking to the streets or finding refuge in gangs in the absence of a loving parent. "Victims of migration," was how the youth in our research group called these children left behind. La Esperanza is part of an international federation of popular education organizations in Latin America that calls itself a "movimiento de educación popular y promoción social" [movement for popular education and social advocacy]. Its founder in El Salvador was one of the six Jesuit priests killed by the military in 1989 who, along with Archbishop Oscar Romero, have become "martyrs" who are emblematic of the popular movement in El Salvador. While La Esperanza had a long presence in the community of El Rio, the bachillerato (high school) had only just opened the year of our research. Both La Esperanza and the Lincoln School, then, served grades K-12, but our research focused on students in high school, or bachillerato in the Salvadoran system.

\section{Methodological Overview}

We spent ten months from September 2008 to June 2009 conducting participantobservation and interviews at these two schools. Our fieldwork took different forms in each of the two schools, although it had important elements in common. At the Lincoln School, which followed a U.S. school calendar, fieldwork was stretched out over the ten-month period. During the first four months, my coresearcher began regular classroom observations, while we both attended staff meetings, assemblies, and special events, and I began attending service-learning trips. Beginning in January 2009, when the Salvadoran school year began and the bachillerato opened at El Rio School, we began an intensive schedule of participant-observation at both sites. We spent two days each week at each school (Mondays and Tuesdays at El Rio; Wednesdays and Thursdays at the Lincoln School), and used the fifth day to attend field trips and other special events as they came up in either school. From January through May each of us logged over 100 hours of classroom observation at each school, for a total of 400 hours. We observed classrooms, 
staff meetings, staff development sessions, and school assemblies, and in the case of the Lincoln School, naturally occurring activity in the libraries, courtyards, and cafeterias (El Rio did not have a cafeteria or functioning library). We attended school celebrations, field trips, and service-learning projects and wrote extensive field notes. We conducted over 60 in-depth interviews with students, teachers, and administrators and organized a series of focus groups with high school students at both schools. We also administered a survey to the senior class (or bachillerato students, in the public school) to obtain basic socioeconomic data and information on ties to the United States for families in each school, and collected a variety of documents from student work, essays, artwork, poetry, etc., to official bulletins, newspaper articles, and statistical information.

Fieldwork at El Rio was conducted entirely in Spanish, while at the Lincoln School, a bilingual school, both English and Spanish were used. Students at the Lincoln School were given the option of conducting interviews in whatever language they felt most comfortable in; most students, having received instruction in English since Kindergarten, chose to speak English. Salvadoran teachers at the Lincoln School generally chose to use Spanish with us, while American and Canadian teachers spoke in English.

Although our fieldwork at El Rio School was more concentrated, occurring over a six-month period as compared to ten months at the Lincoln School, it included additional layers of data collection which allowed a level of depth and intensity not achieved at the Lincoln School. At El Rio, we had the opportunity to develop a participatory research "course" with ten bachillerato students, in which the students conducted interviews and observations in their communities, wrote reflections, and met regularly with us to analyze our collective data. Through our intensive interactions with these youth researchers, described below, and our access to their data and reflections, we were given a privileged perspective on youth civic identity in El Rio. We did not have this opportunity at the Lincoln School, for a number of reasons, the most important being the rigidity of the schedule at the Lincoln School and the lack of time or flexibility to engage in activities not already programmed. At El Rio there was an openness to our intervention due to the newness of the school (the bachillerato was in its first year and administrators were still working out the schedule), a less rigidly defined and constantly shifting class schedule, and a school vision and mission that shared the goals of our participatory research, as defined below. Below I provide profiles of civic education at both schools, before discussing our participatory research project and the implications for civic identity formation. All personal names have been changed to protect confidentiality.

\section{Civic Education at the Lincoln School}

At a Lincoln School assembly celebrating national Independence Day in September 2008, elite Salvadoran students listened quietly to a speech given by the minister of tourism. The minister, the parent of a ninth grader at the school, talked of his new propaganda campaign exhorting Salvadorans to beautify and invest in their country. One ad was titled, Sé un turista, mantén limpio tu país (Be a tourist, keep your country clean). In the speech the minister called on Salvadorans to be like the foreigners who come to their country to pay homage to their natural and cultural patrimony. It is they who know how to appreciate what we have, he told them. Throughout the city the ads could be seen on billboards, bus stops, and street signs: "Sé un turista en tu propio país." The message was clear: be like them and not like us. The school's choice of speaker on this symbolic occasion of national identity and pride-Independence Day - and the content of his message reveal a "pro-North American" conception of citizenship, in which students were taught that the most important models for improving their country came from abroad. 
The Lincoln School had a two-pronged mission to prepare bilingual, bicultural students to be successful in a global context, and to contribute to the development of El Salvador, or "national uplift," in the words of the Superintendent. The latter goal was frequently expressed by teachers and students as "educating the future leaders of the country." Yet in spite of this explicit goal to play a leadership role in civic life, the high school had no formal civic education program or class. The school's American curriculum, in the minds of many students and teachers, contributed to a "pro-North American" conception of citizenship in which students imagined their futures in the United States or Canada. Students did not study Salvadoran history or politics until their senior year, in a required course called "Salvadoran Studies." All classes were taught in English except Salvadoran Studies and Spanish literature; and even the Spanish language and literature textbooks were compiled by North American scholars and published by North American textbook companies. Students lamented in a focus group that only one week at the end of the term was devoted to Salvadoran authors.

We chose to regularly observe classes where we imagined rich discussions of citizenship would take place: Salvadoran Studies, Sociology, History, and language classes. However, in our extended observations of these and other classes, we heard no references to national citizenship or civic duty by teachers. Even more striking, while our research took place during a historic election year, the presidential campaign was rarely, if ever, discussed in classrooms. Considering the frenzy with which students and teachers were discussing the elections outside of class, its absence from classrooms was marked. In a striking example of this, I arrived to the Sociology class the week after the elections and the historic FMLN victory, curious to see how students would be talking about the election results, only to find the class watching Snow White for the start of a unit on "the media." They watched the film in its entirety. When I later asked the teacher whether he had previously discussed the election results with his students, he said "Oh, no!" He wanted to wait until more time had passed "and feelings have died down" before bringing it up. As surreal as it seemed at the time, I argue that this was reflective of the school's practice of nonengagement, in which teachers regularly avoided discussing local issues with students for fear of touching a political nerve. This practice of nonengagement, together with a student body that was socioeconomically homogeneous, and a "pro-North American" conception of citizenship that did not allow for students' multiple identifications, contributed to the development of complacent civic identities in which involvement in the local context was not a chief concern. However, while school and teacher practices assumed or encouraged "pro-North American" identities, student responses to these practices suggest more nuanced civic identities, and, in particular, a longing to explore their multiple identities and allegiances. Interviews with students and teachers, a student focus group, and responses to the school's service-learning program, described below, illustrate both the perception of the school's pro-North American citizenship vision and students' critique of this.

Interviews revealed that many students and teachers were sharply critical of what they saw as a failure of the Lincoln School to prepare "citizens of El Salvador." A Salvadoran teacher who herself was a graduate of the Lincoln School said, "I don't think anybody knows what it really means to be a citizen of El Salvador... I don't see that kids or anybody is very proud of being a Salvadoran, except maybe on football [soccer] games, soccer ... I don't see that the school is doing anything on that respect." Another teacher, also a graduate of the school said, "We don't emphasize [Salvadoran citizenship]. Most of our kids just want to get out of here." Teachers often spoke of students' family ties to the United States as negatively affecting their identity and commitment to El Salvador. As one American teacher said, "I think students that have family in the States that are sort of doing really well, that they look up to the States as kind of an escape from here completely. I think 
it undermines their ties to El Salvador completely." In our survey of the senior class $(N=76), 93$ percent said they had family members living in the United States, and 99 percent had been to the United States to visit. Of those who had been to the United States, 70 percent said they went at least once a year. Fifty-eight percent said they planned to attend college in the United States next year, with another 24 percent going to another country outside El Salvador. The Salvadoran Studies teacher told us his students were developing a "pro-North American identity."

Students' ties to the United States were clearly visible, but not all students agreed with the perception that these ties in themselves were weakening Salvadoran identity. Some students were quick to point out the school's role in this process, critiquing the projection of a single, North American identity over a Salvadoran one. One student told me that it was a "mistake" for the school to wait until senior year to require Salvadoran Studies. She explained, "I think that's a big part of this feeling of internationals being better than Salvadoran. It's the fact that we lack learning on our country." This student did not feel that the school prepared students to be citizens of El Salvador because, "the school is mostly concerned with seeking education elsewhere... The main goal is to send you away to a school in the U.S." A focus group with the students in AP English became a heated debate on this topic. Students unleashed a volley of critiques about the relative lack of attention given to Salvadoran history and society at their school. One student, Eduardo, attempted to defend the school, arguing that it was up to the students to expose themselves to El Salvador's realities, not the school. But his classmates disagreed. A female student remarked that they learn about George Washington and Abraham Lincoln every year since they were small, but they don't learn anything about Salvadoran history until their senior year. "We need to learn about Maximiliano and Alberto Masferrer," she said. To this Eduardo replied, "There's Wikipedia for that!"

Eduardo's reply illustrates the degree to which students were accustomed to receiving information on their country from the Internet and global media sources, rather than through face-to-face conversations with their teachers. Other students picked up the implications of this for their civic identity. As one female student exclaimed in an interview, "We're in like one of the leading schools of this country, we're supposed to be the future of this country, and we don't know anything about this country!" Another student said that the school taught you to "undervalue what people have in this country." Explaining, he said, "The first choice is always outside (abroad), and if possible to stay there and not return ... It creates a great devaluing of everything that is here. [The school] fails in the area of social conscience, and without conscience, the academic preparation fails, too."10

Students' transnational ties clearly presented a challenge for citizenship education, but more important was the way the school approached this reality, and the choices educators made to engage or not engage students' experiences as citizens of El Salvador. One program that would have exposed students to different realities in El Salvador, and that presented the greatest opportunity for discussions about citizenship, was the servicelearning program. Service learning was a requirement for graduation: seniors were required to complete 30 hours in one of several community service projects that the school arranged for them: from teaching English to students in a rural town, to environmental cleanup projects, to home building with Habitat for Humanity, or working in a home for orphaned boys. The goals of the service-learning program, as explained by the Coordinator, were: (1) to teach students leadership skills (communication, public speaking, organization, etc.), (2) to help poor communities, and (3) to promote interaction and exposure to different social groups. This last goal was considered most important to school leaders. As the service-learning coordinator explained, "The biggest part is for our kids to see these different life styles, to see people that come from different backgrounds than their own and hopefully that's going to instill in them a sense of responsibility." The President of the 
Board, a parent, said that Lincoln students needed "to see how the other half lives," because "our kids live in a little bubble." Many teachers believed the service-learning program played an important role in developing students' civic identities and commitment to El Salvador.

I followed two service-learning projects over the course of the year, from the first orientation meetings to the culminating projects. And I observed several factors that seemed to undermine the goals of the program. First, for all student trips off campus, including service-learning projects, students were accompanied by armed escorts. Usually, a pickup truck carrying two, three, or more uniformed guards with rifles or machine guns followed the school van. By insisting on armed escorts, the school sent a message that identification with poor communities was neither possible nor desirable. The school sent this message in many ways. The administration cancelled service-learning trips frequently, at the slightest threat of bad weather or "security risk." Even trips within the San Salvador metropolitan area were cancelled for heavy rain, or because an armed robbery had recently taken place somewhere in the vicinity. During the month before the elections all servicelearning trips were cancelled, because it was considered unsafe. With each cancelled trip, the opportunities for developing relationships in the service communities were diminished, and students were taught that these communities mattered little to the school, after all.

Some teachers who chaperoned the service-learning trips also communicated this message, demonstrating disregard for the goals of the program. In one Saturday ESL trip to a rural community, as soon as the group arrived at the site, the two accompanying teachers settled themselves on a bench in an adjoining courtyard, not bothering to oversee the students' activities. They remained there for the whole day. On another after-school trip, although the session was late getting started, the teacher chaperone was adamant that the group leave immediately at the scheduled departure time of 4:45, because, she said, "this is a dangerous neighborhood." The students' lesson time was cut short to 20 minutes. With these messages from teachers and administrators, it is no surprise that students did not demonstrate enthusiasm for their projects and completed them only after intense coaxing and prodding by the service-learning coordinator.

The service-learning coordinator, a former Peace Corps volunteer, expressed frustration at her inability to hold the students accountable. Although service learning was a graduation requirement, she told me, "nobody is going to back me up if I try to hold a kid from graduating because they didn't do their service learning." And the fact that she had no class time to work with the students meant that there were few opportunities for debriefing and reflection, so service learning for most students remained a fleeting, surface-level experience. "To be honest, I think a lot of it is propaganda," she confessed. "Because 30 hours, there's only so much English you can teach ... I don't know to what extent we're really helping these people and to what extent we're doing it just for show."

Students also testified to the limited impact of service learning on their civic identities. "It's not going to make anyone more socially responsible if you weren't already," one senior said. Several students said that the most common response of their classmates to service learning was "laziness." As one said, "It's really hard to be touched by three Saturdays." The coordinator suspected that many students felt resentful because of the requirement. An ambivalence about the program's goals was evinced in one boy's comments who said, "I don't think we owe it to society to do it, you know. Like service learning ... I think, we don't owe it to them, but I think we can do good in our society, [so] why not."

Even students who expressed that they enjoyed the service learning and felt that they learned a lot revealed complacent attitudes toward civic participation. When asked what they learned, the most common response was, "to appreciate what I have," or "to 
appreciate my bed!" One student said that she learned from her experience that "they [people in the rural town] have more problems." When asked how that knowledge affected her or changed her attitude, she replied, "Well, I can say that I'm really fortunate because I don't have those problems, right?" Nowhere did students express a need or responsibility to work for change. In fact, the experience may have solidified their sense of entitlement to the privileges they enjoy. As one student said, seeing how little the students in the rural town had made him feel "lucky, and not just lucky, but thankful ... thankful for my Dad's hard work, and my grandfather's hard work, all my family's hard work, that gave me the opportunity to come here, having this education." In his thinking, his ability to be at the Lincoln School was the result of his family's hard work; by extension, the students in the rural town who did not have his opportunities presumably came from families who did not work hard. Nothing encouraged the students to question why students in such different social circumstances had so much less; or why students who were otherwise "just like us" had so many "more problems."

The Lincoln School's approach to service learning resembles Westheimer and Kahne's personal responsibility citizenship, and what some have called a "thin" service model (Koliba 2004), in its deliberate avoidance of politics, discussion, and reflection. Koliba argues that such "thin" approaches, common to U.S. practitioners who fear inserting politics in their teaching, reproduce privatized notions of citizenship and contribute to the "downsizing of democracy." At the Lincoln School, the exposure to difference through service learning without serious opportunities for reflection or dialogue with the "other," seemed to reinforce students' position of class privilege and entitlement. The invitation to "see how the other half lives," without interrogating their own relationship to that reality, seemed to promote apathy. Rather than engaging students in what it means to be a Salvadoran citizen in the context of these realities, the school reinforced the assumption that students "just want to get out of here."

\section{Civic Education at El Rio}

On the morning of March 24, 2009, all of Esperanza School gathered on the basketball court for the annual celebration of Monseñor Romero, commemorating the 29th anniversary of the archbishop's assassination. In the ceremony, a series of skits, songs, prayers, and poems performed by students recalled Romero's life as a defender of justice and resounded the call to action that his death signified. The ceremony was replete with calls to denounce injustice and inequality, demand rights from the government, and work for social change. The Romero celebration is one of the symbolic rituals through which citizenship is embodied at El Rio (Bénéï 2008; Lazar 2010). In posing Monseñor Romero as students' role model, the ceremony reflects a "prolocal" conception of citizenship in which students were taught that their role as citizens was to work for social change on behalf of the poor and oppressed in El Salvador. Indeed, the vision of La Esperanza School in El Rio is to serve the "excluded population" with a quality integral education, to "prepare people of few resources to become agents of change in the society in which they live." This vision was firmly grounded in the local community of El Rio, where students experienced the realities of poverty and injustice daily. The school's aspirations are perhaps best captured in the words of the Social Studies teacher, who explained his goals for his students by saying: "I would like for a student to come to me one day and say, 'I want to become a professional and to return to work in El Rio.'"

In its vision and mission and in public ceremonies like the Romero celebration, El Rio School modeled a social justice conception of citizenship in which social critique and the need for social change were emphasized. But in the everyday practices of discipline and pedagogy, educators reflected a personal responsibility citizenship, emphasizing values of 
responsibility, honesty, and respect, and the need for individual behavioral change, in ways that were sometimes at odds with its social justice vision. Educators were seemingly unaware of the contradiction between structural and individual explanations for poverty and inequality that these approaches entailed. In everyday discourse, educators frequently faulted the "lack of values" of parents or students for the problems their students faced.

Like the Lincoln School, El Rio had no formal civic education program or class (although the Social Studies curriculum included "civics"). Instead, its values-based education was visible in numerous "actividades de convivencia," or community-building activities integrated into the curriculum and in cocurricular activities like camps, workshops, and spiritual retreats. Students in the high school had a class called "Community," which met once a week, and a psychologist's workshop series held during the school day called "Creative Conflict Resolution." In my analysis, these classes demonstrated the tensions between the social justice and the personal responsibility citizenship visions, and in particular, between individual and collective analyses of and solutions to social problems. The Community class, according to its teacher who was also the religious education teacher, aimed to promote students' personal growth and give them an "experience of community life which they might not get in their homes or communities." At the beginning of the year, students were invited to form their own groups of six; these would be their "communities" for the rest of the year. Each group was asked to identify five values that would characterize their group and discuss how they would put them into practice. In subsequent classes, groups were instructed to act out one of their values in short role-plays for the class. There was no discussion about why they had chosen the values they did or why they mattered. Students generated their values and skits hurriedly and haphazardly. Following the chaotic skits, the teacher admonished them for not taking the activity seriously, and gave them a minilecture on the importance of effort and responsibility. These routine disciplining lectures, a mainstay of daily classroom life in our observations, consistently placed the focus of attention on students' attitudes and behavior, constructing students as objects of remediation, rather than agents of change.

Occasionally in Community, students had the chance to share personal experiences and support each other in confronting the challenges of their lives, and in my observation, these personal discussions were the one space where students displayed a level of seriousness, respect, and attentiveness that they did not demonstrate in their other classes. The classroom was transformed into a space of support, with students sharing often-painful personal experiences, sometimes crying and exchanging hugs and other gestures of solidarity. According to the teacher, the goal of Community was to "generate a climate of respect where [students] can discover, individually, the importance of values and on the basis of that . . . be able to live their lives." Her emphasis on students' individual discovery of values was noteworthy, and was in seeming contradiction with the collectivist goals of the class. Arguably what was transformative about the sharing of personal experiences was the collective nature of these experiences, and students' realizing that their experiences of suffering were shared. But the shared social context that gave rise to their experiences was never discussed.

Even actividades de convivencia that clearly promoted a collectivist approach to problem solving avoided discussing students' daily experiences with social problems. In Community students participated in several games and activities in which they had to work as a team, and learned, in the words of one student, that "the obstacles you have, however difficult they are, can be confronted and overcome better by working together than alone." But in failing to engage the context that produced the conflicts they addressed, these activities often seemed to suggest to students that the only change necessary was within themselves. For example, a typical workshop session with the psychologist would include 
breathing exercises to promote relaxation and several fun activities to build self-esteem. In one such activity I observed called "the magic box," students had to think of something positive to say about one of their classmates, to whom they handed the magic box, continuing until everybody had held the box. Even the activity's title, "the magic box," suggested something otherworldly and ephemeral about community. Activities such as these were aimed at combating the effects of social dislocation, poverty, and violence on students' lives without involving students in analyzing or addressing the root causes of these problems.

While I frequently saw teachers use dinámicas, or games and activities that had the potential to provoke rich discussion on social issues, I seldom saw teachers connect these to discussion of students' lives. In one Community class where students had acted out the "fable of dialogue, collaboration, and violence," illustrating the futility of violence to solve problems, the teacher asked them, "Is violence good?" and was predictably greeted by a chorus of "no!"s. She passed out a handout with rich discussion questions only a few minutes before the end of the period. As was frequently the case, there was no time for discussion.

It must be noted that the physical conditions of teaching and learning at El Rio School were extremely taxing and adverse to thoughtful discussion or reflection. Teachers in the bachillerato endured cramped spaces, few materials, poor ventilation, a high level of outside noise sometimes reaching deafening proportions, and a constant stream of interruptions of all kinds. Class periods regularly started late or were cut short by administrative interruptions or sudden changes to the schedule. All of these obstacles clearly interfered with teachers' ability to promote serious engagement among their students. There were also many other factors influencing the school's citizenship education practices that are beyond the scope of this article, including the faith traditions represented in the school's founding and leadership, the mandates from the Ministry of Education, the quality of teachers' education and training, the conditions in the community, and so on. What I mean to point out in this brief case study is the absence of attention to students' experiences of transnational realities, including especially the experience of inequality, and the implications this neglect had for students' evolving civic identities. In spite of the school's social justice-oriented vision, teachers' citizenship education practices remained fleeting and abstract, decontextualized from students' everyday lives. The students in our participatory research group, to be described below, were sensitive to these contradictions and to the lack of attention to what they called "our reality."

\section{Participatory Research as Civic Education}

Several weeks into our observations, we obtained permission to work with a group of first-year bachillerato students, ranging in age from 15 to 19 , in a participatory research class focused on migration and citizenship. We initially recruited 18 students, nine each from each of the bachillerato sections we had been observing (bachillerato técnico contador and general $)^{11}$ based on our interactions with them and their demonstrated willingness to engage in reflective discussion. But ten students ultimately decided to stay with the group through its conclusion. Several students dropped out when they realized the project would require work outside of class, or that we would sometimes meet more than once a week. We emphasized that the project was voluntary, but required a commitment, and we worked with the ten students who chose to stay.

Our purpose in involving the youth, in keeping with the goals of participatory research, was to build on and enhance their own capacities for critical analysis and social action while generating a richer knowledge base about the experience of migration. Participatory action research with youth has grown in popularity in recent years as a means of both 
democratizing research and transforming learning, giving young people the tools to investigate and address social problems that affect their lives (Cammarota and Fine 2008). ${ }^{12}$ Because this method aligned well with El Rio School's social justice mission, our proposal was enthusiastically received by school administrators, who gave us classroom space and time during the school day. ${ }^{13}$ We met with the youth weekly and sometimes twice weekly over a four-month period, in a series of focused sessions in which we presented them with our research questions, engaged them in discussion about these topics, and invited them to participate as coresearchers of their communities. Our group meetings served a dual purpose of focus groups generating insights into how the students thought about these questions, and training the students in qualitative research methods. Students conducted observations in the school and community, wrote reports and reflections, and conducted at least one formal interview each; in our group meetings we discussed findings and analyzed our data collectively. Our collective inquiry and reflection proved to be a stimulus for powerful discussions on citizenship, and we learned that students were eager for the opportunity to talk about their experiences of migration and identity in school.

To structure our research process, we used the Freirean technique of "generative themes" (Freire 1999), in which we selected from their responses key themes for further discussion and exploration. The four questions we explored were: What does it mean to be an educated person? What does it mean to be a citizen? How does education prepare young people here to be citizens? and How is migration affecting this community? For each question we posed to them, we solicited their individual reflection and written responses to the question, then discussed their responses in pairs, small groups, and as a whole group. At the next meeting, we would reflect back to them a theme that had emerged from their responses, and pose it as a question for further probing. Inevitably, the generation of themes led to a spontaneous exchange of different opinions and reflections, as students responded to each other's points, offered examples, and sometimes argued with each other. From these discussions my cofacilitator and I selected homework questions to guide their own research activities, to explore the topic in the wider community. When students returned with their observations and reflections, we engaged in a deeper level of discussion.

One of the first themes that emerged in our discussions of citizenship was that of inequality: in particular, the violation of citizenship rights for the poor. Students' initial responses to the question of, "What does it mean to be a citizen?" were full of the language of "rights and responsibilities." So we asked them, "What are the basic rights of citizens?" The group immediately generated a list: education, housing (vivienda digna), nutrition, clothing, health care, security (safety), decent work, and a living wage. Before we could ask them about citizens' responsibilities, one student immediately protested: "iestos derechos no se cumplen!" [but these rights are not granted!]. There ensued a heated discussion about how each right is denied in El Rio. After one student described the different kinds of substandard houses that exist in El Rio, and others discussed the barriers to getting an education, Karina, a soft-spoken, thoughtful girl said it was because they live in a "zona de riesgo" (high risk zone, the equivalent of the ghetto). This indicated an awareness, apparent throughout our discussions, of the unequal distribution of rights based on where you live, and a shared identity as members of an oppressed community. In other discussions students discussed the unequal application of the law for "la clase baja," arguing that government officials who embezzle thousands get off without punishment, while if "we get caught with petty theft, they send us to Mariona" (a notorious high-security prison). Karina shared a local saying illustrating this inequality: "tanto tiene, tanto vale" [you are what you have]. In a society where wealth determines worth, the students suggested, the notion of equal rights is a sham.

Having established students' shared experience and identity as members of a group that was denied citizenship rights, we asked them: What are the options for citizens 
when their rights are denied? How do people respond? Students answered this question based on their own experience, then conducted observations and interviews in the community. The research question became, "¿Que hace la gente para salir adelante cuando se les niega sus derechos?" [What do people do to get ahead when their rights are denied?] The answers they generated included: protest (long discussion about the inefficacy of protest in El Salvador); violence and delinquency (from murder and extortion, to drug dealing and petty theft); emigrate; sell goods in the informal economy; get trained in a trade; use remittances to start a business ${ }^{14}$; combine remittances with other earnings; prostitute; send your children to work; and work in the maquilas (factories with notoriously poor working conditions and wages). Together we classified these actions as destructive actions, actions for survival/subsistence, and actions for social change, knowing there was some overlap. For example, students pointed out that gangsters' killings, the most obviously destructive actions, are also acts of survival, since the law of the streets is "kill or be killed." Two of the students chose to interview gang members, and a third interviewed a deportee, offering intimate glimpses into nonstate sanctioned means of survival. Through these interviews and our discussions, students came to understand destructive and/or stigmatized behavior as evidence of a broken social contract: in a situation where the government does not bestow citizenship rights, citizens do not submit to its laws.

Migration, then, emerged as a theme before we asked about it: as a creative response to the denial of citizenship rights at home, but one that results in further fragmentation and social disintegration. We quickly learned that our students associated migration with social disintegration. Of our ten students, two had a parent living in the United States, and a third had seen her father deported back to El Salvador after 5 years in the United States. All ten students had some family member(s) in the United States, and all of them knew personally someone who had been deported. In the sample of El Rio students surveyed $(N=54), 76$ percent had family members in the United States; 19 percent had immediate family members there (father, mother, or sibling). In contrast to the Lincoln School, only one student ( 2 percent) had ever been to the United States, but because of students' contact with deportees and migrants, they had a high level of familiarity with the life of undocumented immigrants in the United States.

Students were quick to bring up the harmful effects of migration on those left behind. As Alicia put it, "for every migrant who leaves, there are two new gangsters (pandilleros)." She was referring to the migrant's children left behind, who turn to gangs for social support. In their written reflections, all students highlighted family separation and its associated problems as the primary consequence of migration on their community. After listing all the things that can go wrong when a parent migrates, Edgar concluded his reflection with this: "los jóvenes por la ausencia de los padres busca[n] un mal camino y ahí se estanca el progreso no solo de la comunidad sino también en el país" [young people in the absence of a parent fall into the wrong path, and that stalls the progress not only of the community but also of the country]. Some of the problems we discussed were: increased crime and gang activity among unsupervised youth, neglect and abuse of children left behind, school desertion and other schooling problems, dependence on remittances, and identity conflicts for those who migrate. Students shared examples of each of these from their own experience and the testimonies of the people they interviewed (three chose to interview a "victim of migration": the left-behind child of a migrant, or a deportee). The words of Jenny, whose father had been deported, summarized the sentiments of the group: "Es cierto que en este país no hay muchas oportunidades de empleos pero el hecho de emigrar a otro país causa mucho sufrimiento para su familia y el mismo" [It's true that in this country there are not many job opportunities, but the fact of emigrating to another country causes much suffering for the migrant and his family]. 
At the end of our project, we compiled our findings and prepared a presentation of our research at Universidad Centroamericana (UCA) entitled, ${ }^{15}$ "Education, Migration, and Citizenship: A View from El Rio." The presentation at the university assumed symbolic importance for the youth as an expression of their transformation and their aspirations for social change. Initially many of them doubted their ability to present in a university setting, but they committed to preparing for it and embraced the opportunity to share their knowledge. When one student, Jaime, expressed reservations, noting that "we can't be compared to university students, because we're not at that level," a fellow student, Yanira, assured him this way: "they [university students] are going to have a more advanced vocabulary, but we bring knowledge of our reality." The students also noted that by going to present at the university, they would be breaking the stereotypes about young people from their community, because "they'll see that we're not all gangsters."

An analysis of students' reflections at the end of the project, in group discussions and taped interviews, shows evidence of active, critical civic identities, rooted in an intimate knowledge of and commitment to their community. While throughout our research students had said that being "successful" would surely mean leaving El Rio, by the end, the students expressed pride in being from El Rio, because, as Yanira put it, "we are in touch with society's problems, because we live them every day." Students testified that they appreciated the opportunity to explore their "reality" that the research provided. Yanira shared, "[la investigación] me hizo darme cuenta de lo que estábamos viviendo; que tal vez no me había puesto a pensar o a analizar" [(the research) made me realize more what we live, that maybe I had not stopped to think about or analyze before]. The experience made her rethink her plans for the future:

Antes, cuándo yo fui al [instituto nacional] yo empecé a estudiar hotelería y turismo porque me gusta bastante lo que es el turismo ... pero enfocándolo bien, poniéndome a pensar después de esta investigación, me gustaría mejor de cambiar de carrera. Un tanto más de ser cómo socióloga, de meterme más en la realidad en que vivimos. Entonces, sí quisiera estudiar eso, lo que es sociología o antropología.

[Before, when I attended [national institute], I started to study hospitality and tourism, because I really like tourism ... But I've started thinking after this research, I think I would rather change my career, to something more like sociology, to get more involved in the reality in which we live. So, I would like to study that, sociology or anthropology.]

Significant here are her reasons for choosing a new course of study: the desire to "get more involved" in her own reality.

Another student, Karina, also expressed a new vision for her future:

"Entonces yo decía que iba a comprar una casa allí [menciona una colonia bonita] e iba a llevar a mi
familia a vivir allí. Ahora como después de la investigación y viendo la realidad de uno, no, yo quiero
ayudar, yo quiero aportar. Yo quiero ser parte del cambio. Que yo quiero ser parte del cambio porque
sí hay en mí ahora una esperanza que sí se puede cambiar" [I used to think that I was going to buy
a house (in a nice neighborhood) and take my family and live there. Now after this research and
seeing the reality people live, no, I want to help, I want to contribute. I want to be part of the change.
I want to be part of the change because I do have hope now that things can be changed].

She further marked her identity as a change agent when she said she did not think she was like other Salvadorans.

"Hay personas que les da igual pasa lo que pasa, les da igual. En cambio yo, o sea, trato de ver la realidad, la injusticia. Hay personas que no, les da igual 'Ni modo, no se puede cambiar' dicen, no luchan" [There are people who couldn't care less what happens, it's all the same to them. In contrast, I try to see the reality, the injustice. There are people who couldn't care less, "Oh, well, it can't be changed," they don't struggle]. 
Similarly, Elias said he was not like other Salvadorans because he had no desire to migrate to another country. Explaining, he said:

\begin{abstract}
"Creo que la realidad aquí es bastante extensa, bastante amplia para decir o para vendarme los ojos y decir todo está bien y irme para otro país y quedarme con los brazos cruzados. Y no hacer nada por el país ... Yo creo que haría más aquí que en otro país" [I think the reality here is too wide, too complex, to blindfold myself and say everything is fine and go to another country and stay there with my arms crossed, and not do anything for the country. I think I would do more here than in another country].
\end{abstract}

Elias expressed a view common in our research group that people who migrate only improve their own situation, but not that of the community they left behind.

These students expressed their aspirations for social change in the context of defining themselves as citizens, assuming the responsibility to work for change as a core aspect of their identities. Even in the context of extreme hardship, they suggested, it is not enough to survive and get out. As Yanira put it: "Hay muchos que se niegan a ver más allá de sus narices ... si bien se quieren superar, se quieren superar solo para ellos mismos, y no para tal vez cambiar en donde vive, para ayudar a los demás. Entonces, no sería igual que ellos." [So many refuse to see beyond their noses. If they do have ambition to succeed, it is to succeed only for themselves, and not perhaps to change where they live, to help the rest. So no, I wouldn't be the same as them.]

\title{
Conclusion
}

The voices of young people in these two San Salvador communities bear witness to the challenge of becoming citizens in sending countries within transnational social fields. At the Lincoln School, among families of economic resources, the promise of superior higher education and job opportunities in the United States leads teachers and students to focus on gaining entry to U.S. colleges, encouraging a "pro-North American identity" to facilitate successful transition to life in the United States. At El Rio, the economically precarious situation of the community presents emigration to the United States as a survival strategy, undertaken in the absence of opportunities to improve one's situation locally. With so much pointing them toward the United States, to be a Salvadoran in El Salvador, one El Rio student told me, is "luchar contra viento y marea" [to struggle against wind and tide].

My experience with the youth in El Rio suggests that participatory research offers a way to engage students in examining the paradoxes of becoming citizens in highly unequal, transnational social fields. In doing so, it becomes a form of civic education that creates active civic identities, in which students develop an increased sense of agency and responsibility to contribute to the conditions of democratic citizenship. My findings echo those of Rubin (2007) and Abu El-Haj (2009a) in suggesting that the opportunity to explore disjunctures in citizenship, particularly the experience of inequality and marginalization in the context of global migration, can be a powerful stimulus for the development of democratically oriented civic identities. For the students in El Rio, the opportunity to examine their reality and their place in relation to structural relations of inequality was a key step in the transformation of their identities from "victims of migration" to agents of change. Their success in projecting their new identities at their presentation caused the school principal, who had been in the audience, to exclaim, "I didn't know we had students like these!"

My findings also suggest that, for students who experience transnational realities from the position of sending countries, failure to examine the conditions that cause so many to migrate might lead to complacent or discouraged civic identities that reduce the possibilities for democratic social change. It seems that an awareness of extreme inequalities in their home country, without the opportunity to explore the causes or consequences for 
their lives, promotes detachment and apathy, expressed as complacency among children of privilege at the Lincoln School, and discouragement among children of poverty in El Rio. Students in both schools seemed to be longing for ways to make sense of the place of their home in the context of global inequality. It may be that when the primary model of personal success and upward mobility is to migrate abroad, educators have a more urgent responsibility to engage students in exploring their local context. The eagerness with which students in both schools talked to us about the meaning of Salvadoran citizenship in the context of migration underscores the importance of this topic to them and the need to incorporate it into the formal educational process.

At the same time, I am aware of the dangers of advocating participatory research as a model for school-based citizenship education. Educators at El Rio and the Lincoln School were under a host of pressures and constraints that shaped what they were able to do in the classroom, while, as outside researchers, we had the luxury of engaging students without being subject to those pressures. The findings of this study should serve less as a normative evaluation of the school-based citizenship education programs analyzed here, than as a lesson for other researchers of civic education, who have choices about the methods they use. As Mason and Delandshere (2010) write, researchers who care about the aims of civic education-participation and action, dialogue and deliberation-should strive to model these in their research methods. The most common forms of civic education research, based on comparative methodology using standardized measurements across different contexts and fixed-design approaches, position subjects in a passive role, and fail to capture the evolving local meanings and understandings of citizenship (Mason and Delandshere 2010; Rubin 2007). As citizenship becomes increasingly more complex, our research methods must become more open to the experience and participation of young people, who have much to teach us about the needs of effective citizens in the contemporary global context. When we open up our methods to better understand "the experience of living simultaneously within and beyond the boundaries of a nation-state" (Levitt and Glick Schiller 2004), we increase the possibility that our research will contribute to meaningful democratic citizenship formation, engaging students in efforts to define themselves and their purpose in this rapidly globalizing world.

\section{Notes}

Acknowledgments. I would like to thank my research partner, Dr. Enrique Sepulveda, and the students and staff at both schools in San Salvador who welcomed us into their lives.

1. See Hondagneu-Sotelo and Avila 1997; Menjívar and Abrego 2009; Parreñas 2005; and Schmalzbauer 2008.

2. Estimates of Salvadorans in the United States vary widely depending on the source of the data, whether official U.S. sources or Salvadoran ones. Official Salvadoran statistics, from the Ministerio de Relaciones Exteriores de El Salvador, place the number at 2.5 million, and this is the figure regularly cited within El Salvador. The most recent U.S. Census estimates, from the American Community Survey in 2008, calculate the number to be 1.5 million. Given the high number of undocumented immigrants in this community it is likely that they are significantly undercounted by U.S. official sources.

3. Personal interviews at CARECEN, a Salvadoran NGO dedicated to the human rights of migrants, and the Universidad Centroamericana. These figures have likely changed since the global economic downturn.

4. Ministerio de Economía, Dirección General de Estadística y Censos, 2005; cited in "El Salvador: Emigración y remesas." Asociación Equipo Maíz, 2006.

5. The "market basket," more inclusive than the "basic basket," includes the cost of food, clothing, housing, education, and healthcare for an average family.

6. My translation from the Spanish.

7. The Alianza Republicana Nacionalista (ARENA) is the conservative party that had been in power since 1989. 
8. All school and personal names are pseudonyms.

9. This is allowed by an arrangement in El Salvador's education laws.

10. My translation from the Spanish.

11. Accounting and general.

12. For a more detailed description of participatory research theory and method, see Park 1993; Cammarota 2011; and Dyrness 2008, 2011.

13. We arranged to meet when students would otherwise have been in Seminario, a loosely focused seminar covering, among other things, research methods.

14. National data show only 7 percent of remittances are used for this purpose; 92 percent are spent on food, housing, medical care, and education.

15. Universidad Centroamericana is the oldest private university in El Salvador, most famous for the killings of the six Jesuit priests by the military in 1989.

\section{References Cited}

Abu El-Haj, T. R.

2009a Becoming Citizens in an Era of Globalization and Transnational Migration: Re-Imagining Citizenship as Critical Practice. Theory into Practice 48(4):274-282.

2009b Imagining Post-Nationalism: Arts, Citizenship Education, and Arab American Youth. Bénéï, V. Anthropology and Education Quarterly 40(1):1-19.

2008 Schooling Passions: Nation, History, and Language in Contemporary Western India. Stanford: Stanford University Press.

Cammarota, J.

2011 A Sociohistorical Perspective for Participatory Action Research and Youth Ethnography in Social Justice Education. In A Companion to the Anthropology of Education. M. Pollock and B. A. U. Levinson, eds. Pp. 517-529. Boston: Wiley-Blackwell.

Cammarota, J., and M. Fine, eds.

2008 Revolutionizing Education: Youth Participatory Action Research in Motion. New York: Routledge.

Dyrness, A.

2008 Research for Change versus Research as Change: Lessons from a Mujerista Participatory Research Team. Anthropology and Education Quarterly 39(1):23-44.

2011 Mothers United: An Immigrant Struggle for Socially Just Education. Minneapolis: University of Minnesota Press.

Estudios Centroamericanos

2007 Editors' Introduction to Special Issue "Migraciones" 62(enero-febrero):699-700.

Flores, W. V., and R. Benmayor, eds.

1998 Latino Cultural Citizenship: Claiming Identity, Space, and Rights. Boston: Beacon.

Freire, Paulo

1999[1970] Pedagogy of the Oppressed. New York: Continuum.

Hondagneu-Sotelo, P., and E. Avila

1997 "I'm Here but I'm There": The Meanings of Latina Transnational Motherhood. Gender and Society 11(5):548-571.

Huff, J. G.

2007 Democratic Pentecost in El Salvador? Civic Education and Professional Practice in a Private

High School. In Reimagining Civic Education. B. Levinson and D. Stevick, eds. Pp. 69-90.

Lanham, MD: Rowman and Littlefield.

Kandel, W., and D. Massey

2002 The Culture of Mexican Migration: A Theoretical and Empirical Analysis. Social Forces 80(3):981-1004.

Koliba, C. J.

2004 Service-Learning and the Downsizing of Democracy: Learning Our Way Out. Michigan Journal of Community Service Learning 10(2):57-68.

Lazar, S.

2010 Schooling and Critical Citizenship: Pedagogies of Political Agency in El Alto, Bolivia. Anthropology and Education Quarterly 41(2):181-205.

Levinson, B.

2005 Citizenship, Identity, Democracy: Engaging the Political in the Anthropology of Education. Anthropology and Education Quarterly 36(4):329-340. 
Levinson, B., and J. Berumen

2007 Democratic Citizenship Education and the State in Latin America: A Critical Overview.

Revista Electrónica Iberoamericana sobre Calidad, Eficacia y Cambio en Educación 5(4):1-15.

Levitt, P., and N. Glick Schiller

2004 Conceptualizing Simultaneity: A Transnational Social Field Perspective on Society. International Migration Review 38(3):1002-1039.

Levitt, P., J. DeWind, and S. Vertovec

2003 International Perspectives on Transnational Migration: An Introduction. International Migration Review 37(3):565-575.

Mason, T., and G. Delandshere

2010 Citizens Not Research Subjects: Toward a More Democratic Civic Education Inquiry Methodology. Interamerican Journal of Education for Democracy 3(1):6-26.

Menjívar, C., and D. Abrego

2009 Parents and Children across Borders. In Across Generations: Immigrant Families in America.

N. Foner, ed. Pp. 160-189. New York: New York University Press.

Nussbaum, M.

2002 For Love of Country? Boston, MA: Beacon.

Ong, A.

1999 Flexible Citizenship: The Cultural Logics of Transnationality. Durham, NC: Duke University Press.

Park, P.

1993 What Is Participatory Research?: A Theoretical and Methodological Perspective. In Voices of Change: Participatory Research in the United States and Canada. Peter Park, Mary Brydon-

Miller, Budd Hall, and Ted Jackson, eds. Pp. 1-20. Westport, CT: Bergin and Garvey.

Parreñas, R. S.

2005 Children of Global Migration: Transnational Families and Gendered Woes. Stanford, CA: Rubin, B.

Stanford University Press.

2007 "There's Still Not Justice": Youth Civic Identity Development Amid Distinct School and Community Contexts. Teachers College Record 109(2):449-481.

Schmalzbauer, L.

2008 Family Divided: The Class Formation of Honduran Transnational Families. Global Networks 8(3):329-346.

Sassen, $\mathrm{S}$.

2006 Territory, Authority, Rights: From Medieval to Global Assemblages. Princeton: Princeton University Press.

Westheimer, J., and J. Kahne

2004 What Kind of Citizen? The Politics of Educating for Democracy. American Educational Research Journal 41(2):237-269.

Wolf, S.

2009 Subverting Democracy: Elite Rule and the Limits to Political Participation in Post-War El Salvador. Journal of Latin American Studies 41:429-465. 